\title{
Refugee Crisis in North America: Comparative Case Study of the United States and Canada
}

\author{
Zhanna Dossan ${ }^{1}$ \\ ${ }^{1}$ School of Political Science and Public Administration, Wuhan University, Wuhan, China \\ Correspondence: Zhanna Dossan, PhD Candidate, School of Political Science and Public Administration, Wuhan \\ University, Wuhan, Hubei, 430072 China. E-mail: zhanna.dossan@gmail.com
}

Received: November 28, 2020

Accepted: March 27, 2021

Online Published: March 29, 2021

doi:10.5539/jpl.v14n3p59

URL: https://doi.org/10.5539/jpl.v14n3p59

\begin{abstract}
The US continues to lean toward a traditional, negative approach (Gomez, 2018) and to encourage cultural diversity in Canada. In their initial immigration legislation, the Canada and US shared profound resemblances: both began with Euro- and Christian-centered laws in order to limit the influx of migrants from Southern/Eastern Europe and Asia. The researcher has taken an empirical approach to a comparative methodology, and performed a study of the immigration policies of each country empirically. Both qualitative and also quantitative data analysis approaches were used for the present research. The findings of the research suggest that the two countries share some of the foundational similarities concerning their initial immigration law. For instance, this includes the inception of their policies with the base as Euro and Christian policies, where both attempted to achieve restricted migration flow from the Asia as well as Southern/Eastern Europe. However, with time, the changes in the migration policies have occurred due to the diverging socio-cultural as well as geographical aspects.
\end{abstract}

Keywords: refugee, crises, comparative, case, United States, Canada

\section{Introduction}

The reception of refugees has been one of North America's most prominent political controversies over the past three years. Latest national surveys indicate that there has been an obvious difference between the political trends and local views on refugee problems between the Canada and United States (US). The US continues to lean toward a traditional, negative approach (Gomez, 2018) and to encourage cultural diversity in Canada. This concept brought me to the related guiding questions: How do the Canada and US as the twin multicultural democratic countries of North America, relate or distinguish from one another in manner they accept refugees? And how does their experience in the host country impact the local narratives and perceptions of refugees? This research argues that nativism and nationalism were the foundation of the early resettlement laws in both the United States and Canada. With time, however, bureaucratic and geographical obstacles have permitted Canada to take more control over relocation flows, facilitate refugees with better resources, and alleviate national security issues, creating a more liberal and hospitable image as a consequence. Refugee problems in the US on the other hand, remain dominated by a dynamic "Us vs Them" national dialogue, which may promote a more negative sentiment against newly arriving refugees. The US and Canada comparative study will be split into two key areas: (1) the past of refugee entrance and relocation policy decisions, and (2) local narratives and attitudes related to major refugee communities.

A lengthy tradition of anti-immigrant rhetoric against newly arriving populations is ingrained in the US immigration system. Political whims have often relied on the policy pattern that regulates refugee-related matters, primarily the subjective, extremely debatable notion of 'Explanations of Congress' stringent immigration policies also include 1982 Chinese Exclusion Act, which prohibited Chinese refugees from immigrating to The United states, the Immigration Act of 1917, which expanded the immigration cap from China to the whole continent of Asia, and the Immigration Act of 1921/1924, which favored the admission of Europeans.

\section{$1.11940 s-1950 s$}

The notorious tragedy defined as The Plight of St. Louis" in 1939 was the first major political incident reflecting the nationalist stance of the US against refugees. President Franklin D. A German transporter carrying over 900 Jewish refugees, all with their own plot of persecution, was cut off by Roosevelt from Cuba to the US (Facing 
History, 2017). Based on a nationwide poll published at the time, 67.4 percent of Americans claimed that Jews must never be given protection and American issues must be the main primary priority in the wake of the Great Depression and 61 percent opposed wanting to take Jewish children (Kshatriya, 2019). Most of its travelers died in the holocaust when, except for returning to Nazi-occupied Germany, the ship had nowhere else to go.

The Congress of United States passed the Immigration and Nationality Act in 1952 (INA) in answer to a 1951 United Nations Convention Pertaining to the Refugee convention. The Act provided that asylum may be issued if a claimant "may show a justifiable fear of oppression because of religion, race, ethnicity, affiliation in a political opinion or specific social group." The claimant must justify and support their argument in the application process by putting up persuasive facts, such as past oppression, ongoing conditions in their native country that cause the justifiable fear of violence, seriousness of past mistreatment that causes impotence or refusal to return, or other harm not consists of five protective grounds but' severe enough to amount to to ill-treatment" (Robles, 2018).

Amid the United States resolution to enter into the international immigrant rights convention, the 1952 Act posed concerns as to whether the United States had a clear mechanism in place to process the cases of refugees efficiently. In fact, the Act lacked to include any clear protections for refugees and even enabled the Attorney General to determine (at his own discretion) who should be given 'withholding of removal' (Kshatriya, 2019). The essence of enrollment in the US has been highly skewed and murky because of this political choice. Not to take into account, the use of formulal of national origin managed to make it very hard for candidates from outside of the Western Hemisphere to be admitted, given the extremely low proportion of people already living in the United States in that region.

Ultimately, the US government was able to exclude specific groups of migrants from the yearly quota purely on the basis of national security interests, which were largely determined by the struggle against communism at that moment. As a consequence, many immigrants were eventually welcomed to the US by ad hoc schemes in the 1950s. 6,130 Hungarian refugees, for instance, according to the 1953' Refugee Relief Act, escaping the War against the Soviet Union was allowed. A further 30,000 joined the US within the discretionary control of the Advocate General and were given lawful lifelong recognition in 1958, which in the following years set the standard for the administrative role of the Advocate General in refugee immigration (USCIS, 2018).

\section{$1.21960 \mathrm{~s}-1980$}

The U.S. Congress abolished the quota system for the first time in 1965 and instituted seven preferential immigration classes, which included a new genre for international refugees. The refugee limit was estimated at 17,400 at the point (Igielnik \& Krogstad, 2017). However, refugees who applied for refuge were also largely restricted to individuals who had escaped repression in a communist world or a nation in the Middle East region owing to the continued participation of the US in the Cold War (Martin et al, 2013). Likewise, the parole policy of the Justice Department continued to create routes for migrants of special interest to the US to legal residency. The application of this strategy revealed that the government of US was deliberately trying to attract allies from nations whose political philosophies were at conflict with the American democracy.

The special 1980 Refugee Act was passed by Congress, which lawfully embedded the language of the 1951 UN Convention to describe 'refugee status' and created a detailed, consistent approach to refugee enrollment and relocation. The Act abolished the ideological and geographical limits of the meaning of 'refugee', standardized refugee handling procedures, enhanced the annual amount to 50,000, and produced the Office of Refugee Resettlement (ORR) to successfully integrate migrants into American society. Nowadays through operating with notable charitable organizations such as the US Commission for Refugees and Immigrants, the Church World Service, International Rescue Committee and World Relief Corporation, the ORR coordinates location placement and recognizes developmental programs for new immigrants.

During the 1970s, more than 300,000 Southeast Asian refugees left for the US as a consequence of the Indochina Wars, political opinion began to shift. Most significantly, in 1975, the Collapse of Saigon generated a flow of 130,000 migrants from Vietnam escaping South Vietnam, most of whom helped the US during the war (USCIS, 2018). The government of USA began to notice refugee problems as more of a chronic situation as a result of the increasing migrant influx, and thereby embraced the chance to showcase itself as a "safe harbour" for displaced families from all around the globe.

\subsection{0 s to Present}

The US saw a greater influx of migrants from Europe in the 1990s, motivated mainly by people escaping political instability in the Kosovo genocide and Soviet Union (Igielnik \& Krogstad, 2017). Nonetheless the proportion of accepted refugees suffered a dramatic decline after 9/11, when President Bush's Patriot Act decreased the number 
of arrivals to fewer than 30,000 which is a 60 percent reduction relative to the pre-9/11 era. This incident revealed that concerns of security could dramatically undermine the US's dedication to refugee safety in the aftermath of a major terror attack. In 2008 to 2011, the influx of migrants to the US increased again. Most lately, over 12 million Syrians have been forced to relocate by the continuing conflict in Syria. In 2016, under the administration of Obama, over 12,000 of them were granted asylum in the US.

In 2004, the influx of refugees to the United States rose, including half of the estimated approved refugees arriving from Somalia, Cuba, and Laos. Between 2008 and 2011, the US acknowledged last year that between 5,000 and 15,000 Burmese and Bhutanese were fleeing civil wars. Most significantly, the continuation of about 12 million Syrians have been evacuated by the conflict in Syria. 12,587 of them were resettled across the Obama Administration in the US in 2016. Two years later, during the Trump Administration, this figure fell to 62 (Rush, 2018).

At present, the US immigrant entry and relocation figures have not held up with more than 65 million of the world's refugee community (National Immigration Forum, 2019). Recent terrorist attacks carried out by radicals, including the San Bernardino incident in 2015 and the attack of the Orlando club in 2016, have sparked questions among American citizens about the existence of refugees, particularly from Middle East nations (Levenson, 2017). The right-wing policy of Donald Trump, most famously illustrated by his anti-immigration policies, his controversial 2017 ban on Muslim travel, and his stern containment of Central American refugee voyages in 2018 (Del Real, 2019), has contributed to dramatic reductions in the acceptance and relocation of refugees.

All in all, through its immigration policies over the past several decades, the US government has taken a credible move in creating a more multicultural community. Historically, it is recognized that the country has allowed to settle the most refugees and immigrants. However, much of the refugee-related initiatives have often been motivated by strategic factors, including the advancement of the philosophies of the Free World, the duty to favor some categories of migrants over others and the adoption of national defense steps (Hyndman, Payne \& Jimenez, 2017).

\subsection{Canadian Refugee Law}

In the beginning of the 20th century, Canada used to have an immigration system which was discriminatory towards non-European immigrants. However, relative to the US, Canada's immigration rules today are much less reliant on political conditions, making the scheme seem much more robust and effective to applicants applying as a result (Gravelle, 2018). The explanation lies mainly in the assumption that no major global war or cross-state dispute has included Canada. Its remote geographical status also enables the nation to take a small part in global challenges. The connection between a refugee's nationality and the political and social environment of Canada is not that much of a deciding factor in refugee entry and relocation. In fact, in the Canadian society, cultural diversity and nationalism are called inherently linked terms; and this conviction makes the problems of refugees hard to be politicized.

\subsubsection{Late $1800 \mathrm{~s}-1950$}

Canada is like the US a country born out of Europe's obsession with hegemony and colonialism. It is also not shocking that the early immigrant system in Canada was seen as a key method for shaping and preserving a whitedominant population.

The North American Gold Rush can be dated directly to one of the earliest forms. A significant number of Asian immigrants began to settle in the northwestern and western areas of Canada to operate in the mining companies in the middle of the 19th century, because both the Canada and US already had an open attitude. They also took up work in railway building and timber centers in the following decades. The military conflict in China and insufficient economic opportunities in different parts of Asia have acted as drive factors for most of these refugees, and the high incomes and availability of cheap labor in North America have served as underlying factor. The Canadian government tried to close down the influx of Asian refugees into the state during the early 20th century, most prominently by their internal 1923 Chinese Exclusion Act. "Political laws were imposed that limited entry to "American, British, and European migrants" (SICREMI, 2014).

As a consequence of World War I, migration to Canada started to decrease in the 1920s. The small variety of work prospects available in the market have made it an unpleasant location for future colonists both from Europe and the US. The economy of Canada suffered slow population increase and extreme labor shortages during the five following decades.

\subsubsection{0s-Present}

Given its status as among the world's largest socially accommodating nations today (Hancock, 2017), in 
implementing comprehensive refugee policy, Canada was indeed a generation behind the US. Because as postWorld War II economy of Canada expanded steadily in the early 1970s, the nation saw an emerging appetite for qualified workers. In 1976, the migration scheme was finally transformed from one that prioritized ethnic origin to one focused on profession.

Canada often did not accede to whether the United Nations Convention of 1951 or the Declaration on the Protection of Refugees of 1967 until 1969. The state's entrance into international negotiations has resulted in the emergence, under federal legislation of Canada, of migrants as a special humanitarian category of refugees (Molloy \& Madokoro, 2017). Like the US, however, Canada did not establish any systematic initiatives at the moment to investigate migrant applications and proceeded to accept refugees on a case-by-case level (Dirks, 2019).

The Parliament formally announced and institutionalized an open dedication to the UN requirements for refugee protection in 1976, the year that the ethnic background quota was abolished and workforce citizenship was introduced in Canada. A drastic change from Canada's previous immigration policies was the 1978 Current Immigration Act. Also did the Act recognize migrants as a separate immigrant group, but it also called for collaboration between governmental agencies and charitable institutions to help these people transition to the Canadian lifestyle. "In addition to fostering economic opportunity, diversity, and family reunification in the reception and relocation of refugees, Canada has increased the standard of acceptance of refugees to incorporate "gender security and LGBT migrant admissions," a decision that earned UN acclaim in 1986 (Allwright, 5, 2018). Around the same point, though the Act has permitted anyone that would be a detriment to the Canadian community services system to be refused access, such as disabled persons, people with chronic health conditions and people with a criminal history. This contentious decision demonstrated that Canada was concerned in what migrants had to say and was thus slow to consider others who have a poor chance of socio-economic prosperity.

In 1979, Canada started to operate a unique scheme empowering private organizations, such as individuals, charities, and ethnic minority associations, to support foreign refugees as legal immigrants to move to Canada and help them adapt to Canada's fresh start. This initiative illustrated Canada's attempt to make migrants a recognizable part of the national society by leaving power in the hands of all Canadian people (Rose, 2019). About 275,000 refugees were effectively settled through the Private Support of Refugees Scheme as of 2017, which was much greater than the number of state migrants.

Canada stepped back to reassess its immigration policies in the wake of the events of $9 / 11$ in the US but did not cap the number of people moving into the world like the Us did. "In Canada, the amended Immigration and Refugee Rights Act of 2001 only allows the government greater authority "suspected of posing a national defense threat" to arrest and expel landed refugees (Dirks, 2019). Canada performs a key position today in the stabilization efforts of the United Nations, particularly in the current Refugee crises. In 2015, out of the 20,000 registered refugees, almost 10,000 Syrian refugees came under private funding, which indicated that people of Canada were overall involved in assisting with the issue. Though tens of thousands of migrants are trying to acquire a home in the United States, Canada, with a populace of 36 million (less than California's), accepted almost 25,000 migrants in 2018 and emerged the year's \#1 refugee relocation country (Lanard et al, 2019). The rate of relocation was roughly 70 percent (Carman, 2018).

Amid this challenge, Canada is already preparing to lift its yearly cap to 350,000 and maintain its place as the leading relocation nation by 2020 .

In order to understand the immigration policies, the following research questions are addressed:

R1: Is the policy on immigration of Canada more humanitarian than that of USA?

R2: Does Canada use geographical and procedural obstacles to regulate immigration?

R3: What is the attitude of American citizens towards refugees in America?

R4: What is the attitude of Canadian citizens towards refugees in Canada?

In their initial immigration legislation, the Canada and US shared profound resemblances: both began with Euroand Christian-centered laws in order to limit the influx of migrants from Southern/Eastern Europe and Asia. Sociocultural factors and Geographical factors have over time led the basic methods of the 2 countries to differ significantly. The state has become an enticing location for asylum due to the connectivity of the US and its prominent involvement in many big world controversies. The US typically has to contend with the vast numbers of people calling for safety, in addition to its massive population, which can issue of resource access, border protection, national defense, and refugee resettlement will quickly contribute to increased concerns. As a consequence of this politically motivated feeling, refugees in the US are further likely than that in Canada to face regional biases and offer fewer government assistance upon their return. 
"While both US and the Canada have a subjective and objective prong to determine whether the plaintiff has a good reason to fear persecution in the future, the "well-founded fear" test of Canada is more "forward-looking" in itself. This approach means that "evidence of past persecution is not enough to create a fear of future persecution" under Canadian law (Robles, 2018). The "rebuttable presumption" policy in the US grants a claimant who has demonstrated prior persecution the freedom to believe they are likely to experience potential repression. Even though this argument is disproved by US officials, as long as the individual's previous repression meets the degree of seriousness that makes it almost impossible for them all to come back home, the humanistic asylum investigation can still be maintained as a defense in court.

\section{Materials and Methods}

\subsection{Study Participants and Procedures}

The researcher has taken an empirical approach to a comparative methodology, and performed a study of the immigration policies of each country empirically. The investigator conducted comprehensive literary study and textural examination of government policies affecting refugees in each country for this research study. In this research study, case reports, rules, processes, peer-reviewed papers and books are all referenced. In order to evaluate general knowledge and perception of these issues and policies, the coverage surrounding refugee laws in both countries were also studied.

In order to keep the study well balanced, both secondary and primary references were analyzed in this process. In the report, the policies affecting both countries were analyzed. Recognizing these global sources in this report, searching through numerous analysis resources such as internet databases which are readily accessible through the library system, attributable to the wide high quality validated linked papers and peer review articles. The consistency of these services is closely related to the worldwide authenticity of written papers and the strict system of double-blind review that rates these resources among all the best publishing sites. In comparison, the systematic review approach is most widely proposed in the area of social sciences, encouraging potential scholars to establish novel projects on the basis of existing gaps in knowledge in current literature. Older articles published on the topic were extensively studied by the researcher which were extracted from Google Scholar by searching the keywords "American Refugee Policies" and "Canada's Refugee Policies".

For quantitative data collection, different NGOs, government agents and refugees were included as study participants who provided helpful information regarding the refugee policies of both the countries i.e. Canada and the US.

\subsection{Measures}

The data was gathered via a detailed web-based questionnaire consisting of closed-ended questions about the policies concerning refugees in Canada and America. The questionnaires were sent to government officials, NGOs and different refugees via email because of the current COVID-19 pandemic as the researcher could not physically reach out to the participants.

\subsection{Data Analysis}

Data analysis is the procedure that routinely analyses and describes, condenses, recaptures, and analyses data using statistical and/or logical methods. Several analytical techniques offer a way to draw inductive inference from the data and to distinguish the effect from the behaviour caused by the condition of care provided (Shamoo \& Resnik 2003). For research analysis, methods for qualitative and qualitative analysis may be chosen.

Both qualitative and also quantitative data analysis approaches were used for the present research. Until conducting this research, about 30 articles were read for qualitative review. The project abstract was designed after reviewing prior studies related to this subject. Full reading was done of 20 articles that had details important to this report. The most appropriate articles were selected for the compilation of information and analysis of the results of this study. There was a descriptive and thematic analysis of particular publications. The 22nd edition of the Social Sciences Statistical Package (SPSS) was used for quantitative analysis to analyze effects and associations between variables. The tests conducted for this purpose included descriptive analysis, correlation and multiple regression analysis.

\subsection{Ethical Considerations}

One of the most important facets of the thesis may be deemed to be legal questions. The study is predicted to fail if this factor is neglected by the investigators. Academics are professionals qualified to rely on pre-established principles and requirements that define their actions as a branch of the practical ethics of academic study. Various science-related steps begin with the writing and approval of research papers before final examination. And it 
collects and properly archives the data as a text, project document, study, or book.

When conducting evaluations at these points, the researcher must obey the specific statistics. Three key theoretical problems are discussed by a sample-centric experimental study: processing, planning and testing. The role of study involving information exchange, transmission or distribution of facts and, in general, the potential to counter mistakes is provided by guidelines (Wilson, 2010).

The purpose of this analysis was to validate the authenticity and reliability of the study. Study participants were told of their right to secrecy and guaranteed full secrecy about their participation, records and personal information. Respondents were not coerced into the study and engaged in the review willingly by the participants. The participants were protected from potential harm of some sort, and our study proved fair and objective. After the end of the study, the participants were thoroughly informed about the whole procedure.

In this review, the material collected from journals is usable for the general community to use and therefore does not demand any checking from the institutions until presenting a description. To mitigate copyright issues, the records from which the information has been obtained are specified in the reference list.

\section{Results}

\subsection{Introduction}

The study presents the results that are achieved following the use of the mixed research design. The citizens of both the countries such as Canada and the USA are achieved. The focus of the deployed method is on the achievement of the set research objectives, which are as below;

- R1: Is the policy on immigration of Canada more humanitarian than that of the USA?

- R2: Does Canada use geographical and procedural obstacles to regulate immigration?

- R3: What is the attitude of American citizens towards refugees in America?

- R4: What is the attitude of Canadian citizens towards refugees in Canada?

\subsection{Is Canada's Immigration Policy More Refugee-Friendly than That of the US?}

The analysis of the immigration policy has shown that Canadian immigration policy despite being portrayed to be more liberal. The close analysis shows that as compared to the US, the Canadian immigration policy is less refugee friendly. This is based on the fact that various massive backlash is practiced against the refugees, given its positioning in the secluded location along with constraint and restricted measures in terms of the regulatory mechanism. As a consequence of these, the border limits the irregular entries. To make it simpler, the Canadian government is in a more favorable position due to its position as well as a manageable workload. This makes it easy for the country to manage the flow as well as ensure that the right individuals are provided entrance in the country as compared to the US, which has never experienced such a thing.

\subsection{Does Canada Use Geographical and Procedural Obstacles to Regulate Immigration?}

The analysis of the geographical procedure presented various obstacles for the immigration process regulation. For instance, the responses have shown that, in Canada, the geographic, as well as bureaucratic barriers, limit the immigration. The responses show that the geography of the country, as well as bureaucratic structure, limits the immigration of the individual, enabling it to hold a comprehensive regulatory mechanism. Geographically speaking, Canada is observed to be out of the way in terms of everything. Also, the national borders in the Europe might appear to be messy, the borders in Canada are found to be precisely drawn through its geology. It is primarily because of the three cold, vast oceans which limit the reach of the borders to the country. The geography serves as the major reason concerning the isolation from the huge influx of the migrants. This further makes it easy for the Canada government to exercise more freedom as to decide on the ways in which the country is likely to tackle such situations. Since the region has plenty of space available for accommodating the individuals that are refugee, the potential to grow the refugee population is high along with the relative expansion of the workforce to deal with the fundamental concern. The findings of the responses have shown that the policy maker are more inclined to the inclusion of the refugee population in Canada since they serve as an economic advantage and also do not serve as a threat to the national security to the country. Though, the support of Canada to the refugee is not unconditional. Such as the Canadian government makes use of the existing geographical barriers for the imposition of the highly bureaucratic system on the admission as well as resettlement of the refugees, which strives to include only a fraction of the people, which would help in the resource investment, globally.

In comparison to the US, where the individual refugees seek entry using various challenges (where many of these are found to be illegal), where a majority of the refugees have shown that about 20 years of individuals have 
immigrated to Canada, only when the country has provided them with the entry permission. The country Canada only accepts the immigrants that have been provided with the acceptance overseas are provided entry to the majority of refugees. Such as an active and comprehensive screening have been performed for every applicant to the Canadian authorities, where individuals have to wait constantly for years as well as months (Keller, 2018). Although the process causes severe emotional stress to the refugees, however, serves as the major facilitator for abiding to the set rules, as well as orderly movement of the individuals. It has further been highlighted that the individuals who have a front door entry are found to gain more trust as well as acceptance from the public.

In comparison to it, the US is found to have a more laissez-faire approach to resettlement of the refugee. This shows that the US government holds a much integrated process for the migrant initiative, which eventually showcases the country as the one that is more unenthusiastic concerning immigration. Such as the Office of Refugee Resettlement (ORR) does not hold an active position in the resettlement of the refugee. Such as its role is restricted to that of the local state government for providing a blueprint for the plan of the resettlement. Also, the country majorly relies on the major voluntary contribution from the nonprofit agencies for coordinating the placements as well as finding the more effective and appropriate transitional programs for the refugees. In the US, the new immigrants can only predict limited medical as well as cash assistance for an about limited time, such as that of the eight months. In comparison to the Canada, US generally observes to have a high influx of the uncontrollable waves. This is the reason that the US government does not open the flood gates as well as does not guarantee the provision of necessary support to the individuals.

\subsection{Public Attitude}

For assessing the public attitude, the survey was held. This was held based on the findings that it helps in the objective analysis of the attitudes individuals hold towards the resettlement of the refugee in the country. This helps draw the reach picture of the difference between the two countries, such as the US and the Canada, based on their immigrant refuge settlement plans and initiatives. Thereby, initially, the Cronbach alpha value was assessed for the 18 items that were included in the questionnaire. The findings are presented in the Table 1 . The findings denotes that the reliability of the used questionnaire is high, given the value of alpha. The value of alpha is found to be 0.738 , which denote the high reliability of the items used in the questionnaire.

Table 1. Reliability statistics

\begin{tabular}{ccc}
\hline \multicolumn{3}{c}{ Reliability Statistics } \\
\hline Cronbach's Alpha & N of Items \\
\hline .738 & 16 \\
\hline
\end{tabular}

The scale statistics results are presented in Table 2. The findings show that the mean for the items is found to be 32.7790 , the variance value of 17.912 , and the standard deviation value of 4.23228 .

Table 2. Scale statistics

\begin{tabular}{cccc}
\hline \multicolumn{4}{c}{ Scale Statistics } \\
\hline Mean & Variance & Std. Deviation & N of Items \\
\hline 32.7790 & 17.912 & 4.23228 & 16 \\
\hline
\end{tabular}

The gender analysis of the participants selected is also presented in this research. The findings denote that most of these were male, as compared to the number of females present in the research. 
Table 3. Gender

\begin{tabular}{cccccc}
\hline \multicolumn{5}{c}{ Gender } \\
\hline \multirow{3}{*}{ Valid } & Male & Frequency & Percent & Valid Percent & Cumulative Percent \\
& Female & 1437 & 71.4 & 71.4 & 71.4 \\
& Total & 500 & 28.6 & 28.6 & 100.0 \\
\hline
\end{tabular}

The education analysis presented that the most of the respondents who took part in the survey were graduates, following which were the respondents with a master's degree, and the remaining were undergraduate or diploma holders.

Table 4. Education

\begin{tabular}{|c|c|c|c|c|c|}
\hline \multicolumn{6}{|c|}{ Education } \\
\hline & & Frequency & Percent & Valid Percent & Cumulative Percent \\
\hline \multirow{5}{*}{ Valid } & Undergraduate & 57 & 11.4 & 11.4 & 11.4 \\
\hline & Graduates & 286 & 57.2 & 57.2 & 68.6 \\
\hline & Masters & 106 & 21.2 & 21.2 & 89.8 \\
\hline & Others & 51 & 10.2 & 10.2 & 100.0 \\
\hline & Total & 500 & 100.0 & 100.0 & \\
\hline
\end{tabular}

The place analysis among the individuals shows that the majority that took part in the research were from Canada while remaining other such as 188 respondents were from United States.

Table 5. Place

\begin{tabular}{cccccc}
\hline \multicolumn{5}{c}{ Place } \\
\hline & Frequency & Percent & Valid Percent & Cumulative Percent \\
\hline \multirow{3}{*}{ Valid } & Canada & 312 & 62.4 & 62.4 & 62.4 \\
& United States & 188 & 37.6 & 37.6 & 100.0 \\
& Total & 500 & 100.0 & 100.0 & \\
\hline
\end{tabular}

Concerning the analyzed responses, the border strictness' was believed to be high for the Canada, as compared to the United States. This is based on the achieved responses, which majorly agreed to it.

Table 6. Border strictness

\begin{tabular}{|c|c|c|c|c|c|}
\hline \multicolumn{6}{|c|}{ Border strictness } \\
\hline & & Frequency & Percent & Valid Percent & Cumulative Percent \\
\hline \multirow{5}{*}{ Valid } & Strongly Agree & 66 & 13.2 & 13.2 & 13.2 \\
\hline & Agree & 338 & 67.6 & 67.6 & 80.8 \\
\hline & Neutral & 36 & 7.2 & 7.2 & 88.0 \\
\hline & Disagree & 60 & 12.0 & 12.0 & 100.0 \\
\hline & Total & 500 & 100.0 & 100.0 & \\
\hline
\end{tabular}

Concerning the analyzed responses, the easy reach was believed to be high for the United States, as compared to 
the Canada. This is based on the achieved responses, which majorly agreed to it.

Table 7. Easy reach

\begin{tabular}{cccccc}
\hline \multicolumn{5}{c}{ Easy reach } \\
\hline \multirow{4}{*}{ Valid } & Frequency & Percent & Valid Percent & Cumulative Percent \\
\hline & Strongly Agree & 21 & 4.2 & 4.2 & 4.2 \\
& Agree & 389 & 77.8 & 77.8 & 82.0 \\
& Neutral & 39 & 7.8 & 7.8 & 89.8 \\
& Disagree & 51 & 10.2 & 10.2 & 100.0 \\
& Total & 500 & 100.0 & 100.0 & \\
\hline
\end{tabular}

Concerning the analyzed responses, the various entry modes were believed to be high for the United States, as compared to the Canada. This is based on the achieved responses, which majorly agreed to it.

Table 8 . Various entry modes

\begin{tabular}{cccccc}
\hline \multicolumn{5}{c}{ Various entry modes } \\
\hline \multirow{4}{*}{ Valid } & Frequency & Percent & Valid Percent & Cumulative Percent \\
\hline & Strongly Agree & 33 & 6.6 & 6.6 & 6.6 \\
& Agree & 375 & 75.0 & 75.0 & 81.6 \\
& Neutral & 37 & 7.4 & 7.4 & 89.0 \\
& Disagree & 55 & 11.0 & 11.0 & 100.0 \\
& Total & 500 & 100.0 & 100.0 & \\
\hline
\end{tabular}

Concerning the analyzed responses, the Americans favored admission were believed to be high for the United States, as compared to the Canada. This is based on the achieved responses, which majorly agreed to it.

Table 9. Americans favored admission

\begin{tabular}{cccccc}
\hline \multicolumn{5}{c}{ Americans favored Admission } \\
\hline \multirow{4}{*}{ Valid } & Frequency & Percent & Valid Percent & Cumulative Percent \\
\hline & Strongly Agree & 15 & 3.0 & 3.0 & 3.0 \\
& Agree & 476 & 95.2 & 95.2 & 98.2 \\
& Disagree & 9 & 1.8 & 1.8 & 100.0 \\
& Total & 500 & 100.0 & 100.0 & \\
\hline
\end{tabular}

Concerning the analyzed responses, the distrust and harassment were believed to be high for the United States, as compared to the Canada. This is based on the achieved responses, which majorly agreed to it. 
Table 10. Distrust and harassment

\begin{tabular}{|c|c|c|c|c|c|}
\hline \multicolumn{6}{|c|}{ Distrust and harassment } \\
\hline & & Frequency & Percent & Valid Percent & Cumulative Percent \\
\hline \multirow{5}{*}{ Valid } & Strongly Agree & 42 & 8.4 & 8.4 & 8.4 \\
\hline & Agree & 412 & 82.4 & 82.4 & 90.8 \\
\hline & Neutral & 33 & 6.6 & 6.6 & 97.4 \\
\hline & Disagree & 13 & 2.6 & 2.6 & 100.0 \\
\hline & Total & 500 & 100.0 & 100.0 & \\
\hline
\end{tabular}

Concerning the analyzed responses, the high acceptance of refugee in Canada were believed to be high for the United States, as compared to the Canada. This is based on the achieved responses, which majorly agreed to it.

Table 11. High acceptance in Canada

\begin{tabular}{|c|c|c|c|c|c|}
\hline \multicolumn{6}{|c|}{ High acceptance in Canada } \\
\hline & & Frequency & Percent & Valid Percent & Cumulative Percent \\
\hline \multirow{5}{*}{ Valid } & Strongly Agree & 15 & 3.0 & 3.0 & 3.0 \\
\hline & Agree & 398 & 79.6 & 79.6 & 82.6 \\
\hline & Neutral & 44 & 8.8 & 8.8 & 91.4 \\
\hline & Disagree & 43 & 8.6 & 8.6 & 100.0 \\
\hline & Total & 500 & 100.0 & 100.0 & \\
\hline
\end{tabular}

Concerning the analyzed responses, the low emotional distress of refugee in Canada were believed to be high for the United States, as compared to the Canada. This is based on the achieved responses, which majorly agreed to it.

Table 12. Low emotional distress in Canada

\begin{tabular}{|c|c|c|c|c|c|}
\hline \multicolumn{6}{|c|}{ Low Emotional distress in Canada } \\
\hline & & Frequency & Percent & Valid Percent & Cumulative Percent \\
\hline \multirow{5}{*}{ Valid } & Strongly Agree & 27 & 5.4 & 5.4 & 5.4 \\
\hline & Agree & 419 & 83.8 & 83.8 & 89.2 \\
\hline & Neutral & 21 & 4.2 & 4.2 & 93.4 \\
\hline & Disagree & 33 & 6.6 & 6.6 & 100.0 \\
\hline & Total & 500 & 100.0 & 100.0 & \\
\hline
\end{tabular}

Concerning the analyzed responses, the high security procedures of refugee in Canada were believed to be high for the United States, as compared to the Canada. This is based on the achieved responses, which majorly agreed to it. 
Table 13. High security procedures in Canada

\begin{tabular}{cccccc}
\hline \multicolumn{5}{c}{ High security procedures in Canada } \\
\hline \multirow{4}{*}{ Valid } & Frequency & Percent & Valid Percent & Cumulative Percent \\
\hline & Strongly Agree & 15 & 3.0 & 3.0 & 3.0 \\
& Agree & 408 & 81.6 & 81.6 & 84.6 \\
& Neutral & 50 & 10.0 & 10.0 & 94.6 \\
& Disagree & 27 & 5.4 & 5.4 & 100.0 \\
& Total & 500 & 100.0 & 100.0 & \\
\hline
\end{tabular}

Concerning the analyzed responses, the more accommodating attitude of refugee in Canada were believed to be high for the United States, as compared to the Canada. This is based on the achieved responses, which majorly agreed to it.

Table 14. More accommodating attitude in Canada

\begin{tabular}{cccccc}
\hline \multicolumn{5}{c}{ More accommodating attitude in Canada } \\
\hline \multirow{4}{*}{ Valid } & Frequency & Percent & Valid Percent & Cumulative Percent \\
\hline & Strongly Agree & 21 & 4.2 & 4.2 & 4.2 \\
& Agree & 403 & 80.6 & 80.6 & 84.8 \\
& Neutral & 52 & 10.4 & 10.4 & 95.2 \\
& Disagree & 24 & 4.8 & 4.8 & 100.0 \\
& Total & 500 & 100.0 & 100.0 & \\
\hline
\end{tabular}

The correlation analysis presented that there is a high correlation of the refugee influx with the different factors leading to the entrance of the refugee to the countries such as United States and Canada. For instance, influx of refugee was found to be negatively related to the border strictness, while it was positive for the easy reach. The similar was the practice for the various entry modes, which was found to be negatively related to the various modes of entry. Similarly, favored admission led to the huge influx of the refugees, while distrust and harassment limited it. This analysis is based on the achieved value of the $\mathrm{p}$, which is found to be below 0.05 . 
Table 15. Correlation

\begin{tabular}{|c|c|c|c|c|c|c|c|c|c|c|c|}
\hline & & 1 & 2 & 3 & 4 & 5 & 6 & 7 & 8 & 9 & 10 \\
\hline \multirow{3}{*}{ Influx of Refugees } & Pearson Correlation & 1 & $-.820^{* *}$ & $.718^{* *}$ & $-.711^{* *}$ & $.217^{* *}$ & $.309^{* *}$ & $.259^{* *}$ & $.356^{* *}$ & $.339^{* *}$ & $.253^{* *}$ \\
\hline & Sig. (2-tailed) & & .000 & .000 & .000 & .000 & .000 & .000 & .000 & .000 & .000 \\
\hline & $\mathrm{N}$ & 500 & 500 & 500 & 500 & 500 & 500 & 500 & 500 & 500 & 500 \\
\hline \multirow{3}{*}{ Border strictness } & Pearson Correlation & $-.820^{* *}$ & 1 & $.493^{* *}$ & $.421^{* *}$ & $.135^{* *}$ & $.315^{* *}$ & $.117^{* *}$ & $.115^{*}$ & $.221^{* *}$ & $.096^{*}$ \\
\hline & Sig. (2-tailed) & .000 & & .000 & .000 & .002 & .000 & .009 & .010 & .000 & .031 \\
\hline & $\mathrm{N}$ & 500 & 500 & 500 & 500 & 500 & 500 & 500 & 500 & 500 & 500 \\
\hline \multirow{3}{*}{ Easy reach } & Pearson Correlation & $.718^{* *}$ & $.493^{* *}$ & 1 & $.420^{* *}$ & .039 & $.116^{* *}$ & $.335^{* *}$ & $.162^{* *}$ & $.149^{* *}$ & $.224^{* *}$ \\
\hline & Sig. (2-tailed) & .000 & .000 & & .000 & .383 & .010 & .000 & .000 & .001 & .000 \\
\hline & $\mathrm{N}$ & 500 & 500 & 500 & 500 & 500 & 500 & 500 & 500 & 500 & 500 \\
\hline \multirow{3}{*}{ Various entry modes } & Pearson Correlation & $.711^{* *}$ & $.421^{* *}$ & $.420^{* *}$ & 1 & -.083 & $.165^{* *}$ & .055 & $.451^{* *}$ & $.259^{* *}$ & $.093^{*}$ \\
\hline & Sig. (2-tailed) & .000 & .000 & .000 & & .062 & .000 & .220 & .000 & .000 & .037 \\
\hline & $\mathrm{N}$ & 500 & 500 & 500 & 500 & 500 & 500 & 500 & 500 & 500 & 500 \\
\hline \multirow{3}{*}{ Favored Admission } & Pearson Correlation & $.217^{* *}$ & $.135^{* *}$ & .039 & -.083 & 1 & $.372^{* *}$ & $.346^{* *}$ & $.188^{* *}$ & $.128^{* *}$ & $.297^{* *}$ \\
\hline & Sig. (2-tailed) & .000 & .002 & .383 & .062 & & .000 & .000 & .000 & .004 & .000 \\
\hline & $\mathrm{N}$ & 500 & 500 & 500 & 500 & 500 & 500 & 500 & 500 & 500 & 500 \\
\hline \multirow{3}{*}{ distrust and harassment } & Pearson Correlation & $-.309^{* *}$ & $.315^{* *}$ & $.116^{* *}$ & $.165^{* *}$ & $.372^{* *}$ & 1 & $.249^{* *}$ & -.061 & $.411^{* *}$ & $.244^{* *}$ \\
\hline & Sig. (2-tailed) & .000 & .000 & .010 & .000 & .000 & & .000 & .172 & .000 & .000 \\
\hline & $\mathrm{N}$ & 500 & 500 & 500 & 500 & 500 & 500 & 500 & 500 & 500 & 500 \\
\hline \multirow{3}{*}{ High acceptance in Canada } & Pearson Correlation & $.259^{* *}$ & $.117^{* *}$ & $.335^{* *}$ & .055 & $.346^{* *}$ & $.249^{* *}$ & 1 & -.031 & $.170^{* *}$ & $.200^{* *}$ \\
\hline & Sig. (2-tailed) & .000 & .009 & .000 & .220 & .000 & .000 & & .491 & .000 & .000 \\
\hline & $\mathrm{N}$ & 500 & 500 & 500 & 500 & 500 & 500 & 500 & 500 & 500 & 500 \\
\hline \multirow{3}{*}{$\begin{array}{l}\text { Low Er } \\
\text { Canada }\end{array}$} & Pearson Correlation & $.356^{* *}$ & $.115^{*}$ & $.162^{* *}$ & $.451^{* *}$ & $.188^{* *}$ & -.061 & -.031 & 1 & $.172^{* *}$ & $.453^{* *}$ \\
\hline & Sig. (2-tailed) & .000 & .010 & .000 & .000 & .000 & .172 & .491 & & .000 & .000 \\
\hline & $\mathrm{N}$ & 500 & 500 & 500 & 500 & 500 & 500 & 500 & 500 & 500 & 500 \\
\hline \multirow{3}{*}{$\begin{array}{l}\text { High security procedur } \\
\text { Canada }\end{array}$} & Pearson Correlation & $.339^{* *}$ & $.221^{* *}$ & $.149^{* *}$ & $.259^{* *}$ & $.128^{* *}$ & $.411^{* *}$ & $.170^{* *}$ & $.172^{* *}$ & 1 & $.318^{* *}$ \\
\hline & Sig. (2-tailed) & .000 & .000 & .001 & .000 & .004 & .000 & .000 & .000 & & .000 \\
\hline & $\mathrm{N}$ & 500 & 500 & 500 & 500 & 500 & 500 & 500 & 500 & 500 & 500 \\
\hline \multirow{3}{*}{$\begin{array}{l}\text { More accommodating attitud } \\
\text { in Canada }\end{array}$} & Pearson Correlation & $.253^{* *}$ & $.096^{*}$ & $.224^{* *}$ & $.093^{*}$ & $.297^{* *}$ & $.244^{* *}$ & $.200^{* *}$ & $.453^{* *}$ & $.318^{* *}$ & 1 \\
\hline & Sig. (2-tailed) & .000 & .031 & .000 & .037 & .000 & .000 & .000 & .000 & .000 & \\
\hline & $\mathrm{N}$ & 500 & 500 & 500 & 500 & 500 & 500 & 500 & 500 & 500 & 500 \\
\hline
\end{tabular}

The model summary results are presented in Table 16 . The results show that the value of $\mathrm{R}$ is observed to be 0.932 , while the $\mathrm{R}$ square value is observed to be 0.851 , and an adjusted $\mathrm{R}$ square value of .851 , and standard error of the estimate with a value of 18627 . 
Table 16. Model summary

\begin{tabular}{llllll}
\hline \multicolumn{5}{c}{ Model Summary $^{\mathbf{b}}$} \\
\hline Model & R & R Square & Adjusted R Square & Std. Error of the Estimate & Durbin-Watson \\
\hline 1 & $.923^{\text {a }}$ & .851 & .851 & .18627 & .793 \\
\hline a. Predictors: (Constant), Strict Entry regulations, Governance structure, Geography & \\
\hline
\end{tabular}

The ANOVA results are presented in Table 17, the results denote the value of sum of squares to be 98.618 , a df value of 3, and a mean square value of 32.873. Apart from it, the F value is denote to be 947.454, and a significance value of 0.000 . The results show the high predictive value of the strict entry regulations, governance structure, and geography for the influx of the refugees. This analysis is based on the achieved value of the $\mathrm{p}$, which is found to be below 0.05 .

Table 17. ANOVA ${ }^{\mathrm{a}}$

\begin{tabular}{llrrrrr}
\hline \multicolumn{7}{c}{ ANOVA $^{\mathbf{a}}$} \\
\hline Model & & Sum of Squares & df & Mean Square & F & Sig. \\
\hline 1 & Regression & 98.618 & 3 & 32.873 & 947.454 & $.000^{\text {b }}$ \\
& Residual & 17.209 & 496 & .035 & & \\
& Total & 115.827 & 499 & & & \\
\hline
\end{tabular}

a. Dependent Variable: Refugee influx

b. Predictors: (Constant), Strict Entry regulations, Governance structure, Geography

The findings of the coefficient are presented in Table 18. The results show the B value of 0.457 , a standard error of 0.045 , and a t-value of 10.267 . The results denote that there is a significant impact of the geography and strict entry regulation on the influx of the refugees, while the government structure showed no impact on the influx of the refugees. This analysis is based on the achieved value of the $\mathrm{p}$, which is found to be below 0.05 .

Table 18. Coefficients ${ }^{\mathrm{a}}$

\begin{tabular}{|c|c|c|c|c|c|c|}
\hline \multicolumn{7}{|c|}{ Coefficients $^{\mathbf{a}}$} \\
\hline & \multirow{2}{*}{ Model } & \multicolumn{2}{|c|}{ Unstandardized Coefficients } & \multirow{2}{*}{$\frac{\text { Standardized Coefficients }}{\text { Beta }}$} & \multirow{2}{*}{$\mathrm{t}$} & \multirow{2}{*}{ Sig. } \\
\hline & & $\mathrm{B}$ & Std. Error & & & \\
\hline \multirow{4}{*}{1} & (Constant) & .457 & .045 & & 10.267 & .000 \\
\hline & Geography & 1.124 & .023 & 1.100 & 48.798 & .000 \\
\hline & Strict Entry regulations & -.345 & .019 & -.401 & -18.577 & .000 \\
\hline & Governance structure & .006 & .016 & .007 & .341 & .733 \\
\hline
\end{tabular}

a. Dependent Variable: Refugee influx

\section{Conclusions}

This chapter provides an insight into the overall findings that have been achieved following the deployment of the suggested research objectives. The aim of this chapter is to briefly summarize the findings of the research, highlight the main insight, and suggest the area that could further be explored by the future researches.

The findings of the research suggest that the two countries share some of the foundational similarities concerning their initial immigration law. For instance, this includes the inception of their policies with the base as Euro and Christian policies, where both attempted to achieve restricted migration flow from the Asia as well as Southern/Eastern Europe. However, with time, the changes in the migration policies have occurred due to the 
diverging socio-cultural as well as geographical aspects. Given the fact that US has great accessibility as well as active role in majority of the conflicts that are held globally, the country serves as an attractive destination for the refugees. Apart from it, the given the large population of the country, the country has to deal with immense volumes of individuals that ask it to provide them protection that has led to an increased concern over their problem. This concern is majorly found to relate to the availability of the resources, border control, national security as well as refugee integration. Given the political charged sentiment, the US refugees are more inclined to experience local prejudice as well as receive less support from the government upon their entry as compared to that in Canada. Also, the research further presented that individuals who claim Canada to be friendlier in terms of policies for the refugee are generally being neglected to the major part.

The major part is that the position of the Canada resides far away from that of the other emigration hotspots. As a result of it, the country is provided much more liberty related to the way it caters to the needs of the refugees, and aids them to overcome the crisis situation. With the continued effort for maintaining much control as possible concerning every aspect related to the admission and resettlement of the refugees, where the country continues to generate sufficient and appropriate integration of the resources for the entered refugees, following the elimination of the negative politics out of the policy decisions, which enable the provision of a much safer environment for the refugee. Overall, it can be summed up that the US has a much hostile approach for responding to the entry of the refugees primarily because of their influx. Whereas, the approach of Canada is found to be more friendly because they can afford to be nice.

\subsection{Limitation and Future Directions}

The findings of the research are found to be conclusive given the set research objective. However, the reached conclusion highlight that the research results emphasize the future researches to consider more aspect when comparing the policies of the two country. This means given consideration to the other aspects including the external environment, location, and more, which help enrich the data related to the refugee settlement.

\section{References}

Allwright, J. J. (2018). Media Framing of Refugees in the United States and Canada. ProQuest LLC.

Carman, T. (2018). Canada's Acceptance Rate of Asylum Seekers Is the Highest in 27 Years - Here's Why |CBC News. CBCnews, CBC/Radio Canada.

Del Real, J. A. (2019). With Trump's Tough Deterrents, Many Asylum Seekers on the Border Are Giving Up. The New York Times.

Dirks, G. E. (2017). Immigration Policy in Canada. The Canadian Encyclopedia.

Gomez, A. (2018). Fewer Americans Believe the US Should Accept Refugees. CNN, May, 24.

Hancock, E. (2017). The 25 Most Tolerant, Progressive, and Environmentally Friendly Countries in the World. Business Insider.

Hyndman, J., Payne, W., \& Jimenez, S. (2017). The state of private refugee sponsorship in Canada: Trends, issues, and impacts. policy brief submitted to the government of Canada.

Igielnik, R., \& Krogstad, J. M. (2017). Where refugees to the US come from. Pew Research Center, 3.

Keller, T. (2018). Canada Has Its Own Ways of Keeping Out Unwanted Immigrants. The Atlantic, Atlantic Media Company. Retrieved from www.theatlantic.com/ideas/archive/2018/07/canada-immigration-success/564944/

Kshatriya, K. (2019). Introduction to International Refugee Law. First Lecture: INTL 190 - SP19. La Jolla, UC San Diego.

Kshatriya, K. (2019). Introduction to International Refugee Law. First Lecture: INTL 190 - SP19, 4 Apr., La Jolla, UC San Diego.

Lanard, N. et al. (2019). The United States Is No Longer the World Leader in Resettling Refugees. Mother Jones.

Levenson, E. (2017). How Many Fatal Terror Attacks Have Refugees Carried out in the US? None. CNN, Cable News Network.

Martin, D. A. et al. (2013). Chapter Two: Protection in the United States: Nonrefoulment and Asylum. Forced Migation: Law and Policy - Second Edition, American Casebook Series.

Molloy, M. J., \& Madokoro, L. (2017). Effecting change: civil servants and refugee policy in 1970s Canada. Refuge: Canada's Journal on Refugees, 33(1), 52-61. https://doi.org/10.25071/1920-7336.40448

National Immigration Forum, Cepla, Zuzana. (2019). Fact Sheet: U.S. Refugee Resettlement. 
Robles, M. J. (2018). The Level of Severity Needed for Humanitarian Asylum: A Comparative Case Study of Canadian and American Immigration Laws. Baku State University Law Review, 4(2), 180-185.

Rose, D. (2019). Creating a Home in Canada: Refugee Housing Challenges and Potential Policy Solutions. Rep. Transatlantic Council on Migration, November.

Rush, N. (n.d.). Refugee Resettlement Admissions in FY 2018. CIS.org.

Shamoo, A. E., \& Resnik, D. B. (2009). Responsible conduct of research. Oxford University Press. https://doi.org/10.1093/acprof:oso/9780195368246.001.0001

SICREMI. (n.d.). Canada - Overview of the History of International Migration in Canada. Retrieved from www.migracionoea.org/index.php/en/sicremi-en/238-canada-1-si-ntesis-histo-rica-de-lamigracio-n-encanada-3.html

USCIS. (2018). Refugee Timeline. Retrieved from www.uscis.gov/history-and-genealogy/our-history/refugeetimeline

Wilson, D. (2010). Darwin's cathedral: Evolution, religion, and the nature of society. University of Chicago Press.

\section{Copyrights}

Copyright for this article is retained by the author(s), with first publication rights granted to the journal.

This is an open-access article distributed under the terms and conditions of the Creative Commons Attribution license (http://creativecommons.org/licenses/by/4.0/). 